\title{
SCIENCE
}

A WEEKLY JOURNAL DEVOTED TO THE ADVANCEMENT OF SCIENCE, PUBLISHING THE OFFICIAL NOTICES AND PROCEEDINGS OF THE AMERICAN ASSOCIATION FOR THE ADVANCEMENT OF SCIENCE

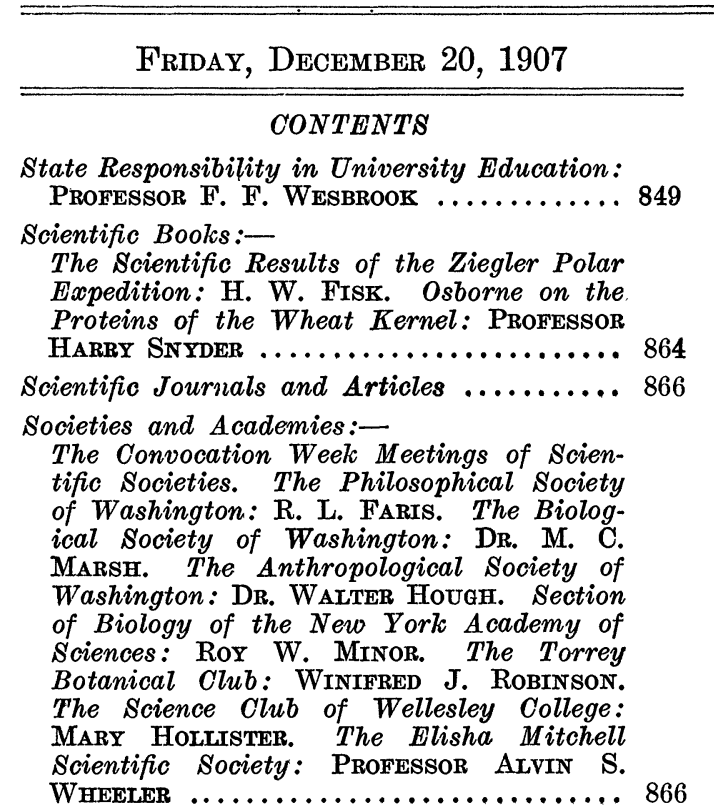

Discussion and Correspondence:-

Lodge's Ether and Huyghens's Gravitation: Professor CARL BARUS. Metagenesis in Insects: Professor Vernon L. Kellogg. Botanical Text-booles: Professor W. J. BeAL ......................... 875

Special Articles:-

The Probable Origin and Physical Structure of our Sidereal and Solar Systems: Dr. J. M. SchaererLe. A Noiseless Room for Sound Experiments: Professor S. I. Franz ..................... 877

The Section of Paleozoology of the Seventh International Zoological Congress: ProFEssor A. W. Grabau ............. 881

The American Society of Biological Chemists. Section K-Physiology and Experimental Medicine-American Association for the Advancement of Science. Biological Section of the American Chemical Society: DR. WM. J. Gies .................... 883

Organization of an American Society of Agronomy ...................... 884

Subscriptions for the Lamarck Memorial.... 885 Screntific Notes and News ............ 885 University and Educational News ....... 888

\section{STATE RESPONSIBILITY IN UNIVERSITY} EDUCATION *

IT is not without trepidation that a son of alma mater appears before you to-day to speak upon a subject whose complicated relations will be apparent to the most casual observer. Even the evidence of maternal interest expressed by the invitation to return to the bosom of the family for a brief visit fails to give assurance in the face of a memory calculated to inspire awe rather than loving remembrance because in the eighties the "propitious mother" restricted her family responsibilities to a periodical and very formal enquiry into the limitations of the student's knowledge. Each of us was left to acquire his sustenance at the breast of a foster mother-the college-for whom love was developed by individual memories not to be expected from the impersonal relations borne to an unnatural, but none the less real and disciplinary, parent. Our university bore us her children, but did not mother or rear us.

Familiarity with the early history of the province and university, a practical knowledge of the workings of the English and German universities and a somewhat lengthy experience in different capacities in an American state university, whilst affording a basis for comparison of view points, methods and educational results, may not, it is true, qualify one to draw deductions as to the responsibilities of the state in university education. The citizens of all

* The second annual opening address delivered by invitation of the faculty of science of the University of Manitoba, at Winnipeg, October 25, 1907. 
free countries are, however, encouraged to believe that each has a right to an opinion and to give voice to his opinion.

Manitoba is unique, not in her provincial or state university, but in the fact that she has limited the power of conferring degrees to that university, and it is eminently fitting when a state decides to establish an educational mechanism that she should control the situation. This assumes what should be the case, that the state is stronger and better able to do what she undertakes than private individuals or corporations and the chief advantage lies in the avoidance of duplication of effort and expense and in the possibility of maintaining a universal high standard throughout the confines of the state.

The education of succeeding generations of students is a matter of great and vital public interest and therefore one with which the state may deal directly if it sees fit. That Manitoba was far-sighted when nearly thirty years ago she decided to place the responsibility and control of education in the hands of the state, is a matter of gratification to us all. That she is still striving for the highest ideals and greatest practical efficiency is indicated by the recent appointment of a royal commission to investigate and make recommendations on university affairs. She naturally wishes to see the limits of her educational responsibilities in order to approach the problem in a business-like way but if her university is to be what the name university implies, namely, a center for the dissemination of all phases of human knowledge, it must be first of all a center for the accumulation of all phases of human knowledge. It is therefore apparent that limitations can not be set nor the future of education be forecast, since it goes hand in hand with or rather should precede and inspire social and economic progress. Indications should be available, however, in ample time to anticipate development along important lines.

Manitoba should and doubtless will avoid the pitfall of young universities which are suddenly confronted with the necessity of having available the most accurate and exhaustive information on every conceivable matter of human interest. Many universities content themselves by meeting their responsibilities on paper and publish multitudinous, awe-inspiring, polysyllabic courses of instruction all out of proportion to the number and qualifications of their staffs. Such dangers may be met by provision for the groundwork of the humanities and the basic sciences with later departmental specialization first along lines which present the most pressing practical and local necessities, or where conditions furnish local opportunities especially valuable to any one branch of knowledge.

A university presupposes, however, that there shall be a continual intake of knowledge on the part of those who are to give it out. This can best be done by a combination of two methods, both of which should be utilized to the fullest extent. The first is stimulation to research and the second is opportunity to know practically and at first hand what has been done and is in the process of completion by other workers along similar or even widely divergent lines.

Research is only possible where ample facilities and time are available in a sympathetic environment. In these days of gauging results in financial terms, the value of research is apt to be overlooked unless it has an immediately practical application. Imagination is often sadly lacking in the so-called practical man who is so likely to be limited in his field of vision if not shortsighted. Ideal results are to be obtained by the cooperation of the man who thinks with the man who works.

Many people use the word research so 
frequently and with such a superior air that it has become hackneyed and the use of the word is apt to provoke a smile. The value, however, of studies or researches in the solution of purely local and commercially assessible problems pertaining to engineering, agriculture, mining, fisheries and matters of public health and animal industry appeals to all. It is when we approach abstruse questions dealing with physics, chemistry, astronomy and the biological and other sciences, that we have difficulty in interesting the general public and demonstrating to localities the need of provision for research. We need not remind ourselves to-day of the contributions of astronomy to practical navigation; of chemistry to commerce, where in many lines, particularly in Germany and even in America, trained chemists, graduates of universities and technical schools are employed; of the recent developments in relation to X-rays ; of practical knowledge concerning the causation of disease, resulting from the study of bacteria and the animal parasites; of increased fertility of soil; of cross-breeding in plants and animals; and of other commercial benefits directly traceable to university researches in these sciences, because even if there seems to be no immediate or remote possibility of practical application to human.affairs, the mere stimulus of an atmosphere of investigation in a teaching institution is inestimable. No teacher can inspire students like an investigator and recognized authority whose life is spent in building stones into the foundation wall of the subject which he professes, and students who have daily opportunities to see new facts brought to light, new methods employed and new conclusions reached are able to secure a vital and definite grasp of important knowledge and find their mental faculties quickened in a way quite impossible to the human sponge who soaks himself full of informa- tion, the original source of which is quite unknown and indifferent to him, but which he learns from a book or lecture. We remember and utilize in after life what we get from actual personal experience or see demonstrated in a practical way, not that which we are dogmatically told by parents, teachers or writers. As has already been said, the professors and staff of a university can not be continually giving out information unless they are continually taking it in. The teaching will be efficient and the reputation of the institution great in proportion to the opportunities which are afforded the instructing staff to advance its own knowledge, of which the most important is individual research.

The second stimulus necessary to the continued growth of the university staff is opportunity to know what is already known. This is not alone to be found in books. Much can be ascertained from books and the current journals, and the absolute necessity of ample provision for a library should need no exploitation, although many universities which do not seem to spare expense in building and equipment are apt to be niggardly in supplying these tools which are essential alike to staff and student. Both teacher and pupil should always refer to the original. It is not enough to know a thing when one may know who said or did it and the conditions under which it was given to the world. A personal acquaintance with the workers of the past can only be secured through their writings and the views which others have had of them. Of present-day workers a knowledge may be had by reading their books, monographs and journal articles but a far more real idea of their methods and view points and of the actual results obtained by them may be secured by personal contact at association meetings, by visiting them in their own environments and working with them in their laboratories. Uni- 
versities should provide opportunities for members of their own staffs to visit other universities and for other teachers and workers to avail themselves of their own local advantages. This is not luxury; it is essential to progress and is demanded, recognized and met by commercial, social and political interests in their own lines of work.

A university professor should not be a compendium of useless information, but the recognized authority in his locality upon the subject professed. He should have ample expert and other assistance.

If the department is railway engineering, the staff should know more about it than any railway interests in the land, so as to be able to advise the state, or, when called upon, the railways. The chemical department should know more than any chemist engaged in commercial pursuits and should be encouraged to develop methods and processes which will be of economic utility to the state. The geologist and botanist should be of great assistance in the practical working out of state interests, particularly in the newer communities. The economists should not be theorists alone, but should be used to the utmost in solving economic questions relating to taxation, banking and business in general. The medical department in each of its specialties should be represented by men preeminently fitted and trained and practical in their temperaments. Law departments should be manned by staffs which have the respect of the bench, bar and general public.

It is apparent that the professor of today must be keen, alert and thoroughly trained and can only be brought and kept up to date by the most strenuous exertion on his own part and liberal opportunity on the part of the university with which he is connected. He must know his own locality thoroughly in order to know how other methods employed in other countries may be applied with advantage to the local problems. He must know facts in books and out of them. He must be able to draw correct conclusions. He must teach and he must have books, and other tools, facilities and assistance. If he is to be an authority on what he professes he must specialize, and to-day we do not have and cannot expect to have a professor of more than one branch of knowledge, although it is not long since a so-called college of the far west advertised in its calendar a "professor of Greek and dancing."

Conditions which govern humanity may be improved in thousands of different ways, and it should be the aim of the state, through its university, to improve the condition of its citizens in every way. The university should lead, not follow. The state should afford a moderate degree of education to every one of its citizens through funds derived from the pockets of all. Whether university training should be given gratuitously to all citizens of the state who have made themselves eligible by a previous course of study is very questionable since in the absence of proper initiative, good judgment and ability to work hard, individuals may be educated out of their sphere, that is, given a knowledge of more facts and methods than they find themselves mentally able to digest and assimilate or to utilize in the ordinary every-day practical affairs of life.

All educational, which must mean research, institutions will probably be run at a loss so far as returns in immediate applicability to the problems of life are concerned. It is therefore necessary for the state or some other force to endow such institutions adequately so as to meet the deficit which results from insufficient payment by those who are taking advantage of opportunities afforded, but whose later labors may return to the state many times over the initial cost. It is very question- 
able indeed whether the citizens of a state should be pauperized by being educated without cost, unless we go to the extreme of communism and leave the state to select early in life the line of activity in which it is to utilize the individual and prepare him for his life work without cost, demanding in return the exercise of the abilities which have been fostered in him by the state. This is a development in socialism to which we shall probably not attain for many generations. In the meantime a middle course may. be selected whereby the individual will be required to make personal sacrifice and expend his own resources in fitting himself for the walk of life selected by him, but for which adequate training will be provided at a financial loss by the university and, according to the basis of our consideration to-day, the state university. In this way, care will be exercised by the individual in the choice of his vocation, appreciation of student opportunities will result, the risk of pauperizing citizens and educating them out of their sphere will be avoided and the educational deficit will be met. This certainly is a good business venture for a state.

Every community is accustomed to grant bonuses to infant industries for the encouragement of commercial interests and to enable them to equip themselves thoroughly and introduce new lines of activity. Most countries levy customs dues on certain manufactured products and even on raw materials so as to develop home production. It is therefore no new point of view to expect a state to provide adequate bonus for a manufacturing plant intended to train succeeding generations of its citizens in a way which will render them capable of taking their places in the world at large and at the same time to develop local resources so as to make their community as commercially independent as possible. This is being done in certain instances. In Minne- sota, the experiments by the university upon wheat-raising, whereby it is now possible to make two or even more stalks of wheat grow where only one grew before, need no comment, and its work on animal husbandry is international in importance. The state of Wisconsin, first by university research and secondly by teaching the principles thus worked out, to its large farming class, has succeeded in producing even a greater revenue through its dairy products than is derived from wheat in its neighboring state, Minnesota. Germany affords perhaps the best example of support of educational institutions by the state, although there is a great difference in the method of working out the problem, as compared with American institutions. The work of von Hoffman on coal-tar products at first seemed to be of mere academic or educational interest, but there are now so many practical applications in dyeing, flavoring extracts, drugs and other synthetic compounds, that we scarcely realize what we owe to a university professor. The work of von Behring and of Koch, backed by governmental university support, has given us antitoxin, on the one hand, and thorough knowledge of tuberculosis, cholera, typhoid fever, anthrax and many other diseases, on the other. Is it not fair to assume that the scientific and technical education fostered by the state in the schools of Germany is responsible largely for her ability to manufacture raw materials into finished products so cheaply as to compete with all nations, even on their home grounds, and in the mere matter of mines to take material which has been thrown away as worthless in the more "rough-andready" American methods and from it make a second vast fortune? In comparing Europe with America we have to class ourselves as extremely wasteful, which was not of so much import, except as it affected habit, whilst the country was 
sparsely populated and the soil still virgin, but it becomes of growing importance with the advent and birth of new citizens and the exhaustion of the soil by repeated crop demands. We all return to mother earth for sustenance and from her bosom we derive life itself.

Each community does wisely if at the very outset it takes stock of its local assets, studies environmental and other conditions which affect operation, and takes immediate steps to utilize its local advantages to the utmost whilst exercising due care for future generations. It is strictly within the function of a university to aid in a practical way. Had the state been developed to its proper point, Edison should have been working in a university and not for his own and others' personal gain; Luther Burbank would have been stimulating colleagues and students by his observations; some national or state university would have sent Walter Reed and Carroll to Cuba instead of leaving it to the United States Army to solve the cause of and methods of protection in yellow fever; Marconi should have been developed in his practical applications as he had been in his theoretical knowledge by a university. In this way the state, that is all the citizens, and not individuals or corporations, would derive more directly the benefits which accrue from advancement in knowledge.

Manitoba can not content herself with teaching the languages, philosophy, mathematics and the sciences as known. She must be engaged in finding out new facts, not only those directly applicable to Manitoba, but those which are of world-wide importance. She must make provision in money, time and opportunity for the members of her university staff to engage in research. Fortunately, she has already secured in her university men who find some time for research and publication of results, but at a personal sacrifice of which the general public knows little or nothing.

This province has a fleeting present, practically no past, but a glorious future. If that future is to be well planned, provision must be made for a thorough study of local resources and the training of citizens properly to conserve and develop those resources. This can not alone be done by study of books or of methods used and results obtained elsewhere, but by practical and prolonged study at home of the local situation; in other words, research must be liberally provided for. This Manitoba will doubtless undertake, one line at a time, thoroughly equipping and fostering each, thus gradually covering the whole field of human activity. Her university should be used in its various departments as the source of expert advice and ultimate court of appeal in all matters pertaining to present knowledge and future progress, not as involving alone a question of Greek roots, history or philosophy, but in such concrete considerations as transportation, mines, public health, agriculture, industrial chemistry, formulation of methods of banking, drafting of new laws and other such practical lines of development, all of which are primarily of public interest, although frequently wrongfully used for purely individual ends.

The scope of the inquiries which the royal commission is expected to make is broad and perhaps it will not be thought impertinent or without the bounds of good taste if an alumnus of this institution, who has followed its development from the beginning until now, should say a few words concerning certain of the provisions given in the appointment of the commission.

THE SYSTEM OF UNIVERSITY GOVERNMENT

The instructions given to the commissioners would warrant the assumption that the present method of university govern- 
ment is cumbersome and not wholly efficient. The executive machinery is of small import if an adequate university staff of the right timber is available, the students are imbued with the proper spirit and the citizens and provincial authorities are in sympathy with the development of a true university. A method of governing university affairs is necessary only in order to stimulate and preserve a proper adjustment of all phases of university activity, to secure the institution against personal selfishness or undue aggressiveness of individuals and to obtain proper representation of all interests: It is surprising to find that Cambridge and Oxford conduct their affairs on republican principles whilst the American institutions are more or less comparable to monarchical governments. Cambridge University affairs are conducted practically entirely by the alumni of the institution. The American state university, with a president at the head, has a board of regents, appointed for a term of years by the governor of the state, or elected by direct vote of the people. The alumni have no voice in the government of the institution except as they may be appointed on the board of regents, or representations are made by the alumni associations to the board of regents and state legislature.

The alumni of the individual colleges which constitute the University of Manitoba are all thoroughly loyal to their colleges and filled with love and reverence for the instructors, past and present. Most of them recognize, however, the incompatibility of denominational college interests with those of general university development. If denominational colleges are to be an integral part of the state university, the activities of these individual colleges should be largely limited to theological teaching and, if so desired, to preparation for the university proper; instruction in lines of general culture including the natural sciences, philosophy, politics and other university subjects, should be provided by the university alone.

The University of Manitoba no longer confines its activities to the examination of students and the conferring of degrees, but has begun the more important part of its work, namely, the actual teaching of its students, and it is surely a more responsible undertaking to convert the raw material into finished product rather than merely to examine and put the label upon the finished product. The teaching work undertaken by the university can and will reach a far higher stage of efficiency by the elimination of duplication in instruction and by the development of broad, general, non-religious-please mark the term, not irreligious-teaching which excludes all tendency to give too early theological interpretation to new facts or view points as presented to students not yet trained to a point where they are able to draw their own conclusions from the premises presented.

It will be noted that the commissioners are instructed to report upon the relationships of the different educational institutions in the province to the provincial university. This may be difficult of adjustment. Consideration of the good of the whole university rather than that of individuals or of local or foreign precedent, together with a realization of the fact that all of the money which goes to support education is derived originally from the people and is, or should be, intended for the benefit of all, will do much to secure what is best for the province as a whole.

A university, college, or school should not be expected to provide exclusively or even largely for the teaching of manners, morals and religion. Something must be left to home influences, and with proper environment in the home and proper ac- 
tivity on the part of the churches, a nonreligious instruction by the state will be found not to interfere with the satisfactory development of religion, but to yield an intelligent citizenship which is not possible in any other way for the same expenditure of effort and capital.

As to the form of university government, no hard and fast lines can be drawn, since each community has its own local problems to solve. In general terms, however, the alumni should have a very large voice in affairs, if they maintain an active university interest and connection. They know, as no others can, what is being done in the university. They know the strong points as well as the weak in their own training. If they have developed themselves as they should after graduation, they are in a position to compare results achieved at home with those secured abroad and, when working shoulder to shoulder with the staff of the university, are capable of giving advice, assistance and support that it is not possible to obtain from any other group of citizens. The faculties certainly should have representation in the general and special conduct of affairs, in the selection of new teachers and in the formulation and realization of a general university policy. The government of the state or province should also be represented, since it has charge of the state or provincial treasury, and has to meet the detailed needs of the province, including interests other than educational. University interests should be so safeguarded, however, that no individual or political party can in any way, or for any purpose, interfere with the proper performance of its function and its natural growth. Those who are interested in the government of universities will find a number of articles in recent issues of SCIENCE by leading educationalists of the United States and a great deal can there be gained which may be of value to Mani- toba, because her problems are very similar indeed to those which confront the various states of the union.

Professor J. McKeen Cattell, of Columbia University, has written a number of articles recently which are instructive and far-sighted, although, at first glance, they appear much more radical than they really are. I may quote from his article on "University Control" : 1

In the colleges from which our universities have developed the problem of administration was comparatively simple. The faculty and the president met weekly and consulted daily; each was familiar with the work of the entire institution; a spirit of cooperation and loyalty naturally prevailed. The trustees also understood the economy of the college and were able to work intelligently for the general good. But when a university covers the whole field of human knowledge, when it is concerned with professional work in divergent directions, when it adds research and creative scholarship to instruction, when both men and women are admitted, when there are 500 instructors and 5,000 students, it is no longer possible for each trustee and for each professor to share intelligently in the conduct of the whole institution. We appear at present to be between the Scylla of presidential autocracy and the Charybdis of faculty and trustee incompetence. The more incompetent the faculties become, the greater is the need for executive autocracy, and the greater the autocracy of the president, the more incompetent do the faculties become. Under these conditions it appears that the university must be completely reorganized on a representative basis. It should not be a despotism and it can not be a simple democracy. Autonomy should be given to the schools, departments or divisions. The administrative, legislative and judicial work must be done by experts, but they should represent those whom they serve.

The present writer ventures to propose tentatively the following form of organization for our larger universities, to be reached as the result of a gradual evolution:

1. There should be a corporation consisting of the professors and other officers of the university, the alumni who maintain their interest in the institution and members of the community who ally

${ }^{1}$ Science, N. S., Vol. XXIII., No. 586, pp. 475477, March 23, 1906. 
themselves with it. In the case of the state universities part of the corporation would be elected by the people. This corporation should elect trustees having the ordinary functions of trusteesthe care of the property and the representation of the common sense of the corporation and of the community in university policy. The trustees should elect a chancellor and a treasurer who would represent the university in its relations with the community.

2. The professors or officers, or their representatives, should elect a president who has expert knowledge of education and of university administration. . .

3. The unit of organization within the university should be the school, division or department, a group of men having common objects and interests, who can meet frequently and see each other daily. It should be large enough to meet for deliberation and to represent diverse points of view, but small enough for each to understand the whole and to feel responsible for it. The size of this group is prescribed by a psychological constant, its efficient maximum being about twenty men and its minimum about ten.

4. Each school, division or department should elect its dean or chairman and its executive committee, and have as complete autonomy as is consistent with the welfare of the university as a whole. It should elect its minor officers and nominate its professors. The nominations for professorships should be subject to the approval of a board of advisers constituted for each department, consisting, say, of two members of the department, two experts in the subject outside the university and two professors from related departments. The final election should be by a university senate, subject to the veto of the trustees. The same salaries should be paid for the same office and the same amount of work. The election should be for life, except in the case of impeachment after trial. The division should have financial as well as educational autonomy. Its income should be held as a trust fund and it should be encouraged to increase this fund.

5. The departments or divisions should elect representatives for such committees as are needed when they have common interests, and to a senate which should legislate for the university as a whole and be a body coordinate with the trustees. It should have an executive committee which would meet with a similar committee of the trustees. There should also on special occasions be plenums of divisions having interests in common and plenums of all the professors or officers of the university. There should be as much flexibility and as complete anarchy throughout the university as is consistent with unity and order.

Professor Cattell states in other articles ${ }^{2}$ that in the development of universities during the initial stages the administrative autocracy of the typical college of the United States will serve its purpose as it has in the past and most effectively, provided the proper man be secured, but that he is to be replaced by some such system of control as has been advocated in the article just quoted. If the various constituent colleges of the University of Manitoba are to confine their teaching to preparation for the university and for theology, it will become necessary for the university to teach the humanities, and this can surely be done with greater success by large departments, well manned and equipped, than by the present methods. The medical college should become in toto what it is now in parte, namely, a true member of the university corporation. These points are of importance in planning for the future in regard to expenditures for buildings, equipment and site. The stimulation afforded by association of those engaged in research, study and teaching of all of the natural and physical sciences, and professions as well as of the humanities is best calculated to bring culture to the one and practicality to the other, whilst the focusing of all branches of university activity under a carefully selected and competent administration will preserve satisfactory relationships and tend to economize in time, effort and money.

\section{UNIVERSITY FINANCES}

The royal commission will probably find difficulty in inducing the citizens and pro-

2 "The American University," Popular Science Monthly, June, 1902; "The University and Business Methods," The Independent, December 28, 1905. 
vincial authorities to realize the magnitude of undertaking to provide a satisfactory university. Although Manitoba has had a university since 1877 , it can not be said as yet to have made provision for it which is at all adequate.

Manitoba has now a population of about 380,000 , and with all the demand on her for increased university facilities, which means expenditure for installation and maintenance, has only been able to expend apprcximately $\$ 80,000$ for building and permanent improvement, and for maintenance $\$ 15,000$ per annum (which until last year was only $\$ 6,000$ ), with an addition of $\$ 25,000$ from land grant and other sources, making a total current expenditure of $\$ 40,000$ per annum.

A comparison with some of the state universities of the middle west which are comparable with Manitoba in the matter of resources, history of development and certain other conditions may be of interest. In order that those who wish to go more minutely into the various questions involved may have the opportunity of so doing, certain tables are appended. Certain of them were prepared and published in the University of Minnesota Alumni Weekly as the basis of an appeal to the state at large and the legislators in particular during the last session.

Minnesota had to begin in a small way and work out her educational problems from the ground, as is the case in Manitoba. Her university was founded nine years earlier than that of Manitoba, but development was going so slowly and the increased demands were so out of proportion to available facilities that the alumni and other interested individuals in the state became aroused and a campaign of general education began.

The development from 1887 to 1906 is shown. In 1887 there were only $412 \mathrm{stu}$ dents registered out of a state population of $1,180,000$ and there was available $\$ 35$,000 from state funds and a total of practically $\$ 70,000$ from all sources, with a total student attendance per ten thousand population of 3.49 . The cost to the state for educating a single student at that time was $\$ 84.94$ and the total cost of the student's education was $\$ 169.24$, with a total per capita cost to the people of the state of less than three cents. In 1906 the population of the state had nearly doubled, being then over two millions, the university attendance had increased to 3,956 , the total funds derived from the state to $\$ 251,464.49$ per annum, the total annual current expense of the university, exclusive of buildings and permanent improvements, was $\$ 542,167.49$ per annum and the attendance at the university for each ten thousand of state population was twenty students. The cost to the state of educating each student had been diminished from $\$ 84.94$ to $\$ 62.86$ and the total cost of the education of the student decreased from $\$ 169.24$ to less than $\$ 140$.

The development of the State University of Illinois from 1859 to 1905 was rapid. The state appropriations for the university were increased from $\$ 60,000$ per biennium (running in 1875 as low as $\$ 11,500$ per biennium) to $\$ 1,153,000$ in 1903 and $\$ 1$,114,525 in 1905 . It must be remembered, however, that the University of Chicago, Northwestern University and very many private, denominational and other colleges in Illinois were being developed synchronously and that the state appropriation for the university has been doubled since 1905 .

Comparative statistics of the various state universities of the middle western states, with some of the endowed institutions, show approximately as many students at the state universities as in the endowed universities, whereas the funds up to $1905-6$ were far less adequate.

For the year 1906 Minnesota had \$542,- 
167 for current expense, whereas the State University of Michigan, the State College of Agriculture and the State School of Mines, three institutions which correspond to Minnesota's State University, had \$1,314,928 available in 1905. Wisconsin and Illinois in 1905 and Iowa and Missouri in 1906 had available the following amounts: Iowa, $\$ 376,000$ to be expended in educating 1,815 students; Missouri, $\$ 571,776$ to educate 2,139 students; Wisconsin, $\$ 714,138$ to educate 3,151 students, and Illinois, $\$ 737,527$ to educate 4,100 students.

The cost of educating a student in the various state institutions varied from $\$ 139$ to $\$ 267$.

Columbia, Chicago and Pennsylvania spent during 1905 or 1906 , as the case might be, between $\$ 1,150,000$ and $\$ 1,766$,000 per annum, whilst Harvard for 1905 spent over $\$ 3,000,000$ for all purposes.

During the legislative sessions of 1905-6 the various state universities became very active and their alumni and other interested individuals brought pressure to bear upon legislatures with very gratifying results. Not all of the exact figures can be obtained but by correspondence, and from other sources some approximate ideas of moneys available have been gained.

Illinois. - It will be seen that a total state appropriation of $\$ 2,207,790$ was made to cover the biennial period beginning July 1, 1907. This does not include funds derived from the federal grant of $\$ 25,000$ per annum, receipts from students' fees and sources other than state grants.

Iowa, which is a strictly agricultural community, and whose population is approximately $2,210,000$, had available for the year 1906 a total of $\$ 550,000$ derived from building tax, permanent fund, interest on endowment, fees and state appropriation. Its enrollment for the year was 2,100 students. Its permanent endowment fund, realized from the sale of land grants, amounts only to $\$ 2,240,500$. The figures for 1907-8 were not yet available,

Wisconsin.-Certain particulars concerning state university expenditures in 1905 have already been quoted and later approximate statistics have been furnished by prominent members of the faculty. She has a two sevenths of a mill tax, which is expected for the years 1907-8 to bring in over $\$ 600,000$ per annum, which, with other funds, will make available for university expenditures for the next biennial period cver one million dollars per annum. This includes a building fund yielding $\$ 100,000$ per year for the next five years.

Nebraska has a population of approximately one and one half millions, with available state university funds amounting to $\$ 590,000$ for the coming year. Figures for 1906 you have already considered.

Michigan has no state university which is comparable with that in Minnesota or Wisconsin, since hér school of mines and school of agriculture are separate state institutions. The exact figures for the coming biennial period are not available, but for the university proper in 1906 the total expenditure was given as $\$ 735,464.52$, which included appropriations of one fourth mill tax for general university purposes. The students' fees for 1906 amounted to $\$ 233$,207.79. For the coming biennial period funds of over $\$ 969,000$ per annum will be available, owing to the increase of the state tax for university purposes from one fourth to three eighths of a mill.

Minnesota, whose population is now in excess of two million, has recently received much more generous financial support, for which the alumni association deserves much credit. The university has just completed during the last biennial period (1905-6, 1906-7) $\$ 874,000$ worth of new buildings and equipment which does not include other permanent improvements. She has available for the coming biennial period an 
amount of $\$ 2,697,000$ which may be even greater, since conservatism has been exercised in the estimates of funds derived from students' fees, the state tax of $23 / 100$ of a mill and miscellaneous receipts.

She is about to erect a $\$ 250,000$ engineering building covered by state funds, a hospital costing $\$ 115,000$ from a bequest of a Minnesota citizen, and is about to increase the size of her campus by a state fund of $\$ 450,000$ which may be distributed over the next three years, but which doubtless will be all completely expended within the next two years, and has a further increase of campus extension fund by the donation to a hospital site fund of over $\$ 40,000$ by citizens of Minneapolis. Her total expenditure for maintenance, exclusive of state grants for hospital maintenance, special investigations, library expenses, repairs, etc., will be over $\$ 663,000$ per annum. Her pay-roll now amounts to over one half million dollars per annum.

The original land grant for university purposes in Minnesota was very much more generous than was realized until quite recently. The state university timber land was once supposed to have value purely for its timber, and the swamp land, when drained, as an agricultural resource. They have been found, however, to be rich in iron. The state auditor estimates that from fifteen to ninety millions of dollars will be derived from these lands, according to the method used in realizing on the ore. A conservative estimate made by him is forty-five million dollars, the annual income of which, when invested, would be available for university purposes, which in addition to her $23 / 100$ of a mill tax, the federal grants which increase annually and students' fees, quite apart from special state appropriations, should enable her, by properly educating her students, to develop state resources, stimulate private and commercial enterprises and improve social and economic conditions. The enrollment of the State University of Minnesota this year will be upwards of 4,400 students and surely it is time now for a proper realization of responsibilities and opportunities. Development of university ideals, a comprehensive plan looking forward to the future, and in general wholesome optimism which sees the future as a definite present obligation, are necessary in order to find the university men and mechanism and the state citizenship and governmental authority ready to meet the gigantic responsibilities and opportunities involved. Minnesota University must awaken to the immediate necessity of an active preparation in order to preserve and utilize intelligently what is in the immediate future. No excuse need be made for presenting in some detail the experience of Minnesota, since her state problems have been-and bid fair to continue to be-very like those of Manitoba. Furthermore, Minnesota conditions are better understood by Manitobans than nearly any other community which is at all accessible.

\section{UNIVERSITY SITE}

Manitoba, like nearly all her sister universities, provincial, state and endowed, has been short-sighted in her original plans for location, but is valiantly endeavoring now to provide for the future. If she is to centralize teaching in sciences, arts and the professions and to establish and maintain an agricultural department, she will require several hundred acres. Every endeavor should be made to bring and keep all portions of the university in as close association as possible and this means, of necessity, the building, equipment and maintenance of lecture rooms, libraries, laboratories, museums, provision for hospital and dispensary service, workshops, horticultural, botanical, agricultural and general biological facilities for outdoor as 
well as indoor experimentation. All of these interests should be associated and fostered under one university and they should be as close to a metropolis as possible. The voice of the pessimist or of the short-sighted individual should not be heeded for a moment. McGill is really cramped for space. Toronto with all the land she had originally, has not sufficient room at the present time to accommodate her new hospital. Columbia has had to move and will have to move again. Johns Hopkins University has not been able to locate all of the various departments in one group. The older universities of Europe suffer from the same failure of imagination. Minnesota has already had to buy at a very great advance in price, additional land for the agricultural department and is now doubling the size of her campus, upon which are located the other departments, at an expense of one half million dollars, and the end is not yet.

\section{UNIVERSITY BUILDINGS}

In planning buildings everything will depend upon the recommendations of the commission as to the nature, scope and methods of teaching which are to be immediately employed. Manitoba will be different from other universities if she is able to anticipate and keep up with the demands for building and equipment. She will doubtless make adequate immediate provision for those departments which are considered most essential, namely, those for which the local need and local opportunity are greatest.

No one can forecast the development of the province, but it will doubtless seem strange to outsiders, and to Manitobans themselves, as they consider it seriously, that a people with the optimism for which Manitoba is celebrated, has not long ere this made definite satisfactory provision for the education of its students along those lines which will be of most value to the development of the province. Optimism to be effective must be consistent and if the good things predicted for Manitoba come true-and we all believe that they will come true-it is time that Manitobans demonstrated an actual practical belief in their predictions by the exercise of an optimistic university policy, casting aside all short-sighted, personal, denominational, political and commercial prejudice. The prairie province will probably profit more by the experience of the states to the south of her than she will by imitating too closely the methods of the older English or European universities, since these were founded at an early period of world development in which conditions were not comparable in any degree to those of to-day. Students of public economy and social development see in the older universities much to admire in the way of tradition and in the way of culture and past accomplishment, but the very traditions and associations which appeal so much to us of the western world are really, when seen at close hand, frequently not to be differentiated from narrow prejudice which prevents them from meeting their own national or local demands and renders utterly impossible a satisfactory reconstruction so as to cope with responsibilities which a state might reasonably place upon her university. The younger universities in England, which are perfecting their professional and technical schools so rapidly, will lack for many years the intangible and often mythical something known as culture, but will furnish brains, utensils and methods which will count for far more in the total of British development. Much must be done by the older English universities if they are to keep pace with the newer universities and technical schools, although they are loath to admit that anything so new and utilitarian can in any sense rival them. 
Manitoba is to be envied that within the next few months the British Association, for the Advancement of Science representing the mother country, and the American Public Health Association representing to a more limited degree and along a more limited line the countries of America, will be convening in her capital city. These distinguished visitors will be anxious to see how Manitoba is meeting her responsibilities and it is to be hoped that the royal commission may be ready to make at least a preliminary report by that time.

We alumni of this university wish to do our part in securing for our younger brothers and sisters everything which they have a right to expect from the province where they are to receive their education and where, for the most part, their life work will be done. The province has only to realize fully what it owes to itself in the way of provision for the strongest arm of provincial development, that is, its university, in order to make a beginning towards the payment of that debt. It must be a matter in which each individual citizen interests himself so that intelligent cooperative action may be taken, and in the process, not only will the total citizenship participate, but individuals will not be found wanting who will realize their opportunities and privileges of doing something for their neighbors and for their own sons and daughters by giving liberally of private funds for public good. The university should not, however, be dependent mainly upon private gifts nor should these be accepted under conditions which will initially or even in far distant years cripple in any way the utility or development of the institution which should be now, and doubtless will soon become, Manitoba's stimulus and guide to progress in all directions. When the possibilities, not merely cultural, but utilitarian, of an ideal university are recognized by the different states and provinces, there will be no need of appeal to public or private interests.

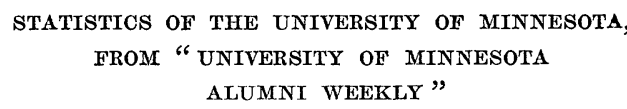

\begin{tabular}{|c|c|c|c|c|c|c|c|}
\hline \multirow{2}{*}{ 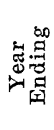 } & \multirow{2}{*}{ 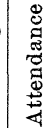 } & \multicolumn{2}{|c|}{ Expęnses } & \multirow{2}{*}{ 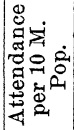 } & \multicolumn{2}{|c|}{$\begin{array}{l}\text { Cost per } \\
\text { Student }\end{array}$} & \multirow{2}{*}{ 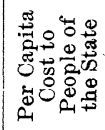 } \\
\hline & & State & Total & & $\begin{array}{l}\text { To } \\
\text { State }\end{array}$ & Total & \\
\hline $887^{3}$ & 412 & $\$ 35,000.00$ & $\$ 69,770.33$ & 3.49 & $\$ 84.94$ & $\$ 169.24$ & $2.966 \mathrm{cts}$ \\
\hline 388 & 491 & & & & 81.47 & 10 & \\
\hline 00 & 781 & & & & 64 & & \\
\hline $890^{4}$ & 1002 & $65,000.00$ & $135,130.86$ & 7.70 & 64.87 & 134.86 & $3.840 \mathrm{cts}$ \\
\hline 891 & 1183 & 65 & 154 & & & & \\
\hline 392 & 1374 & & & & & & \\
\hline 93 & 1620 & & & & & & \\
\hline 1894 & 1828 & & & & & & \\
\hline & 2171 & & & & & & \\
\hline 1896 & 2467 & 12 & 219 & 15.32 & 52.41 & & $8.031 \mathrm{cts}$. \\
\hline 1897 & 2647 & 82 & $283,716.26$ & & 31.10 & 107 & \\
\hline 0 & 2890 & & & & & 10 & \\
\hline 189 & 2925 & & & & 49.51 & & \\
\hline $1900^{5}$ & 3236 & 152,1 & $387,697.83$ & 18.48 & & & $8.68 \mathrm{ct}$ \\
\hline 1901 & 3413 & & 412164 & & & 120 & \\
\hline 10 & 3656 & & & & & 11 & \\
\hline 1903 & 3788 & 18 & & & & & \\
\hline & 3845 & & & & & & \\
\hline 1905 & 3944 & 2.71 & 45 & & 61 & 115.51 & 12.19 cts. \\
\hline $1906^{6}$ & 3956 & $251,464.49^{7}$ & $542,167.49$ & 20.00 & 62.86 & 137.05 & \\
\hline
\end{tabular}

LEGISLATIVE APPROPRIATIONS FOR UNIVERSTTY OF ILLINOIS FROM 1869 TO 1905 INCLUSIVE
$1869 \ldots \ldots \ldots \ldots \ldots \ldots \$ 60,000.00$
$1871 \ldots \ldots \ldots \ldots \ldots \ldots . \quad 130,000.00$
$1873 \ldots \ldots \ldots \ldots \ldots \ldots .651,500.00$
$1875 \ldots \ldots \ldots \ldots \ldots \ldots \ldots \quad 11,500.00$
$1877 \ldots \ldots \ldots \ldots \ldots \ldots .69,500.00$
$1879 \ldots \ldots \ldots \ldots \ldots \ldots .24,000.00$
$1881 \ldots \ldots \ldots \ldots \ldots \ldots . \ldots 20,000.00$
$1883 \ldots \ldots \ldots \ldots \ldots \ldots \ldots \quad 54,500.00$
$1885 \ldots \ldots \ldots \ldots \ldots \ldots .68,000.00$
$1887 \ldots \ldots \ldots \ldots \ldots \ldots . \quad 71,300.00$
$\begin{aligned} 1889 & \ldots \ldots \ldots \ldots \ldots \ldots\end{aligned} \quad 80,150.00$
$1891 \ldots \ldots \ldots \ldots \ldots \ldots . \quad 147,300.00$
$\begin{array}{lll}1893 \quad \ldots \ldots \ldots \ldots \ldots \ldots & 295,000.00\end{array}$
$1895 \quad \ldots \ldots \ldots \ldots \ldots \ldots . \quad 439,900.00$
$1897 \ldots \ldots \ldots \ldots \ldots \ldots . \quad 499,964.81$
$1899 \ldots \ldots \ldots \ldots \ldots \ldots . \quad 521,900.00$
$1901 \ldots \ldots \ldots \ldots \ldots \ldots .6832,330.01$
$1903 \ldots \ldots \ldots \ldots \ldots \ldots \ldots \quad 1,153,000.00$
$1905 \ldots \ldots \ldots \ldots \ldots \ldots \ldots \quad 1,114,525.00$
Total $\ldots \ldots \ldots \ldots \ldots . \overline{\$ 5,665,679.82}$
${ }^{3}$ Population, estimated, $1,180,000$.
${ }^{4}$ Population, 1,301,826.
${ }^{\circ}$ Population, $1,751,394$.
${ }^{6}$ Population, 2,000,000.
${ }^{7}$ Balance left over, $\$ 65,430.23$. 
TABLE OF COMPARATIVE STATISTICS, FROM " UNIVERSITY OF MINNESOTA ALUMNI WEEKIY"

\begin{tabular}{|c|c|c|c|c|c|c|}
\hline \multirow[b]{2}{*}{ Institution } & \multirow{2}{*}{ 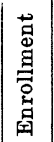 } & \multicolumn{3}{|c|}{ Income } & \multirow{2}{*}{ 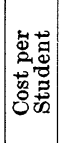 } & \multirow{2}{*}{ 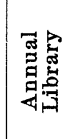 } \\
\hline & & 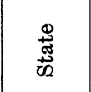 & 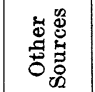 & 蹗 & & \\
\hline $\begin{array}{l}\text { Minnesota, 1906 } \\
\text { Michigan, } 1905^{8} \\
\text { Wisconsin, 1905 } \\
\text { Illinois, 1905 } \\
\text { Iowa, 19069 } \\
\text { Missouri, 1906 } \\
\text { Washington, 1906 } \\
\text { Nebraska, 1906 } \\
\text { Columbia, 1906 } \\
\text { Chicago, 190510 } \\
\text { Pennsylvania, } 1905^{10} \\
\text { Yale, 1905 } \\
\text { Harvard, } 1905^{10}\end{array}$ & \begin{tabular}{|l|}
3956 \\
5734 \\
3151 \\
4100 \\
1815 \\
2139 \\
1194 \\
2914 \\
4833 \\
4580 \\
2692 \\
2995 \\
5393
\end{tabular} & $\begin{array}{r}\$ 251,464 \\
675,284 \\
486,439 \\
401,000 \\
271,500 \\
411,000 \\
149,000 \\
313,000\end{array}$ & $\begin{array}{r}\$ 291,703 \\
639,644 \\
227,699 \\
336,327 \\
104,500 \\
160,776 \\
2,500 \\
130,235\end{array}$ & $\begin{array}{r}\$ 542,167 \\
1,314,928 \\
714,138 \\
737,527 \\
376,000 \\
571,776 \\
151,000 \\
443,235 \\
1,150,000 \\
1,766,332 \\
1,210,728 \\
888,711 \\
3,082,103\end{array}$ & $\begin{array}{r}\$ 139 \\
229 \\
226 \\
180 \\
207 \\
267 \\
125 \\
152\end{array}$ & $\begin{array}{l}\$ 6,500 \\
22,500 \\
38,643 \\
35,000 \\
10,000 \\
10,000 \\
40,000\end{array}$ \\
\hline
\end{tabular}

ABSTRACT OF APPROPRIATIONS MADE FOR THE UNIVERSITY OF ILLINOIS BY THE STATE LEGISLATURE FOR THE BIENNIUM BEGINNING JULY 1, 1907

(Exclusive of other revenues)

$$
1
$$

\begin{tabular}{|c|c|c|}
\hline & $\begin{array}{c}\text { Per } \\
\text { Annum }\end{array}$ & $\begin{array}{l}\text { For the } \\
\text { Biennium }\end{array}$ \\
\hline College of Agriculture & $\$ 50,000$ & $\$ 100,000$ \\
\hline Feeding experiments .. & 25,000 & 50,000 \\
\hline Experiments in corn growing.. & 15,000 & 30,000 \\
\hline Examination of soils & 25,000 & 50,000 \\
\hline Orchard investigations & 15,000 & 30,000 \\
\hline Dairy investigations .. & 15,000 & 30,000 \\
\hline \multirow[t]{2}{*}{ Floriculture investigations } & 7,500 & 15,000 \\
\hline & & $\$ 305,000$ \\
\hline
\end{tabular}

\section{2}

Ordinary operating expenses $\ldots \$ 450,000 \quad \$ 900,000$

Materials for shop practise ... $5,000 \quad 10,000$

Increasing cabinets and collections $\ldots \ldots \ldots \ldots \ldots \ldots$.

Purchase of books, etc., for

Library ...............

Additions to apparatus and ap-

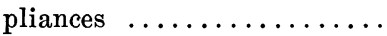

Fire protection ............

Engineering College and Experiment Station ........ 75,000 150,000

Buildings and grounds ...... 14,345 28,690

State Water Survey ....... 6,000 12,000

${ }^{8}$ These figures include the University, the College of Agriculture and the School of Mines, three institutions to take the place of Minnesota's single university.

' Figures for the University alone. Figures for the College of Agriculture not being available.

^ Figures from the World's Almanac of 1905, and include annual income for all purposes.
Draining, etc., on experimental farms $\ldots \ldots \ldots \ldots \ldots \ldots \ldots, 5,000 \quad 10,000$

Department of social and political science .......... 25,000 50,000

School of Music .......... $3,000 \quad 6,000$

Agricultural extension ...... $6,000 \quad 12,000$

Law School ........... 15,000 30,000

Chemical Laboratory ...... $10,000 \quad 20,000$

School of Pharmacy ....... $5,000 \quad 10,000$

Graduate School ......... 50,000 100,000

Veterinary College ........ 30,000

School of Household and Domestic Science ......... 10,000 20,000

Additional equipment of the water station ............

Increasing telephone exchange.

Enlarging general heating and light plant ...........

For purchase of farm land ...

11,600

$\$ 1,502,790$

\section{3}

Physics Laboratory . . . . . . . . . \$250,000

Natural History Hall . . . . . . . . . 150,000

$\$ 400,000$

$\$ 1,502,790$

400,000

305,000

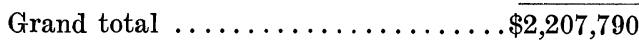

ESTIMATED TOTAL INCOME OF UNIVERSITY OF MINNESOTA FOR THE BIENNIAL PERIOD 1907-8 AND 1908-9

State appropriation for Engineering

Building ............... \$250,000

State appropriation for enlargement of campus ................. 450,000

State appropriation for land, School of

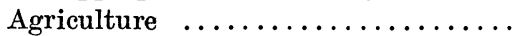

State special appropriations for Univiversity School of Agriculture, Experiment Station and substations, including building, repairs, campus improvement, library and equipment ........... Hospital site fund contributed by citizens Hospital building fund (Elliott estate bequest) $\ldots \ldots \ldots \ldots \ldots \ldots \ldots \ldots$

Hospital maintenance for $1908 \ldots \ldots \ldots$

Current expense, including federal grant, of $\ldots \ldots \ldots \ldots \ldots \$ 60,000$

Special support fund from state ............ 165,000 Interest on invested funds . . . 53,000
76,000

380,000 40,000

115,000 25,000 
Students' fees, estimated .... 140,000

State tax of $23 / 100$ of a mill . 215,000

Miscellaneous receipts from

University and Experiment

Station about $\ldots \ldots \ldots \ldots \ldots \quad 30,000$

Total per annum ....... $\overline{\$ 663,000}$

Total for the biennium ........\$1,326,000

Balances carried forward for expendi-

ture in $1907-8 \ldots \ldots \ldots \ldots \ldots \ldots \ldots, 35,000$

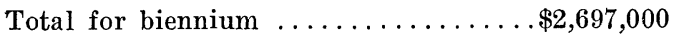

F. F. WESBROOK

UNIVERSity OF Minnesota

\section{SCIENTIFIC BOOKS}

THE SCIENTIFIC RESULTS OF THE ZIEGLER POLAR EXPEDITION $^{1}$

The scientific work of the Ziegler Polar expedition to the Franz Josef Archipelago, 1903-5, commanded by Anthony Fiala, was placed in charge of Mr. W. J. Peters, the representative of the National Geographic Society and second in command of the expedition. Entering the employ of the Carnegie Institution of Washington shortly after his return, as commander of the Magnetic Survey yacht Galilee, he was unable to attend personally to the reduction and to the publication of the results. The completion of the work was therefore entrusted to Mr. John A. Fleming, of the Department of Terrestrial Magnetism of the Carnegie Institution of Washington, who has put it in its present form.

The principal observations were upon the earth's magnetism, with notes and sketches of the aurora, meteorology, the tides and the topography of the archipelago, supplemented by astronomical observations for precise geographical positions. It is to be regretted that the party was not prepared to attempt more in the study of the geology and biology of the region. Mr. Fiala notes in his introduction

1 "The Ziegler Polar Expedition, 1903-1905, Anthony Fiala, Commander." Scientific results obtained under the direction of William J. Peters, representative of the National Geographic Society in charge of scientific work. Edited by John A. Fleming. Published under the auspices of the National Geographic Society by the estate of William Ziegler, Washington, D. C., 1907, 4to, pp. viii +630 , with 43 inserts and 3 maps. to the volume that some interesting fossils were seen, and numerous veins of coal discovered, the latter find proving of practical as well as of scientific interest.

More than one half of the volume is devoted to the results of the observations on terrestrial magnetism. A small magnetic observatory was erected at Teplitz Bay, in which observations were made from September, 1903, to July, 1904, very near the site of the magnetic station of the Abruzzi expedition of 1900 . The observatory was left standing, with the probable expectation that it will be available for future use. In view of the very extended series of results obtained by this expedition, a future series at the same point would have a greatly increased value.

In the discussion of the declination results, some interesting conclusions are drawn as to the character of the daily movement of the needle, during the several seasons of the year. By dividing the entire time over which the observations extend into periods of four weeks each, and plotting the means of the hourly values, each value based on about 240 separate readings, a series of graphs has been constructed, very clearly showing the change in the amplitude of diurnal variation with the time of the year, the times of principal maximum and minimum positions, the epochs of mean declination, and the existence and form of the secondary maximum and minimum. In a further discussion the relation of the mean yearly amplitude of the diurnal variation to the magnetic latitude is again pointed out, and the change in this relation with the epoch in the sunspot cycle is shown.

A large amount of meteorological information was collected on the expedition, which will prove useful in future discussions; its full value, however, was unfortunately affected by deficiencies in the instrumental outfit used. Two very satisfactory series of tidal observations were made at points approximately 150 miles apart. These have been arranged and discussed by Mr. L. P. Shidy, chief of the Tidal Division of the United States Coast and Geodetic Survey, who concludes that the tide wave reaches the archipelago by the two channels on either side of Spitzbergen, the one 